\title{
Solute Uptake, Isotherm and Kinetic Studies for Distillery Wastewater Treatment for Removal of Organic Matter by Low Cost Adsorbent
}

\author{
P. D. Amale ${ }^{1}$, K. S. Kulkarni ${ }^{1}$, Dr. S. J. Kulkarni ${ }^{2}$, A. D. Kulkarni ${ }^{1}$ \\ ${ }^{1}$ Department of Chemical Engineering, Bharati Vidyapeeth University College of Engineering, Pune, \\ Maharashtra, India \\ ${ }^{2}$ Chemical Engineering Department, Datta Meghe College of Engineering, Airoli, Navi Mumbai, \\ Maharashtra, India
}

\begin{abstract}
In the era of rapid industrialization, the effluent treatment has become important area of investigation. The green and sustainable technology is the need of the modern society. Many industries emit the pollutants through effluent. The presence of organic matter is major environmental concern in many industries. The distillery effluent contains large amount of organic matter in it. In the present investigation adsorption with wood charcoal activated carbon was used for organic matter removal in batch experiments. The optimum values of the parameters like contact time, initial concentration, $\mathrm{pH}$ and adsorbent dose was obtained. The data was analyzed for isotherm and kinetic studies. For $100 \mathrm{ml}$ of effluent with $5997 \mathrm{mg} / \mathrm{l}$ initial COD, the optimum parameters were, contact time of 40 minutes, adsorbent dose of 8 grams and $p H$ of 7 . The solute uptake followed both, Langmuir and Freundlich isotherm reasonably well. First order kinetic expression explained the solute uptake more accurately than second order. Though second order equation also satisfactory described the solute uptake.
\end{abstract}

Keywords: adsorbent, adsorbate, kinetics, isotherm, concentration

\section{INTRODUCTION}

In the developing country like India agro-economy is very important aspect of economic growth. Majority of the population depends on farming. Sugar factories are considered as the most important cooperative movement in the developing countries. The use of molasses for ethanol production is growing and it helps to increase the economical viability of sugar industries. Distillery waste water (stillage) is 10 times of ethanol produced. Treatment of distillery effluent is serious problem. This effluent contains high amount of organic and inorganic pollutant. Organic matter is very harmful in the waste streams as it reduces the dissolved oxygen(DO) in the water. If this wastewater is disposed to the river, sea or reservoir, it decreases the DO of the water and thereby affects adversely the aquatic life. The chemical oxygen demand(COD) is the amount of oxygen required per unit volume of effluent for chemical decomposition of organic matter. The conventional treatment includes the use of primary, secondary and tertiary treatments. Primary treatment includes physical separation of pollutants by bar screens, secondary treatments are biological treatments like activated sludge process(ASP) and tertiary treatments are chemical treatments and /or advanced treatments like, membrane separation techniques. Adsorption is very important method in the treatment of wastewater. Various adsorbents are used for adsorption of organic matter from the effluent. The use of low cost adsorbent for the wastewater treatment is increasing day by day. The wastewater from various industries is treated successfully by various investigators. Ahmad and Hameed investigated the reduction of COD and colour of dyeing effluent from a cotton textile mill by adsorption onto bamboo-based activated carbon[1]. Mohan et. al. treated the wastewater by using the adsorption by agricultural waste adsorbent [2]. Ahamaruzzaman carried out studies on utilization of flyash for organic matter removal [3]. According to his studies flyash was good low cost adsorbent for wastewater treatment. Studies were carried out to investigate the role of dissolved oxygen on adsorptive removal of organic matter by Vldlcand Saldan [4]. Ghodale and Kankal carried out COD 


\section{P. D. Amale et al.}

removal by using low cost adsorbents.[6]. They treated sugar industry effluent in their experiments. The adsorbent dose of $3.5 \mathrm{gram} / 100 \mathrm{ml}, \mathrm{pH}$ value of 4 and contact time of 180 minutes were optimum parameters for initial COD of $6820 \mathrm{mg} / \mathrm{l}$. Kulkarni et.al used flyash as an adsorbent for distillery effluent treatment[7].They obtained the COD removal up to 80 percent. Similar studies were carried out by Shah et.al [8]. Various investigators have used various low cost adsorbents effectively for the effluent treatment. Low cost adsorbents like saw dust, bagasse pith, rice husk ash, activated coconut shell powder controlled burnt wood charcoal, flyash, peat, wood, jute fibers have been used successfully by investigators.[9.10].Other biological and non biological methods like membrane techniques have also been used for $[11,12]$.Electro coagulation, biological reactors, anaerobic digestion, solar detoxification have also been investigated and results obtained were encouraging $[13,14,15,16]$. Krishna and. Yenkee used coconut husk for adsorption preparation for wastewater treatment [17]. Naghizadeh et.al.used continuous adsorption experiments to study efficiency of the carbon nanotubes (CNTs) for removal of natural organic matters (NOMs) from aqueous solution[18]. They observed that the break through period was longer at lower initial NOMs concentration. multi wall carbon nanotubes (MWCNT). During investigation, single wall carbon nanotubes (SWCNT) exhibited 53.46 and $66.24 \mathrm{mg} / \mathrm{g}$ adsorption capacity respectively. Ademiluyi et.al. used activated Carbon prepared from waste Nigerian bamboo for adsorption and treatment of organic contaminants[19]. They obtained 60 percent COD removal.

\subsection{Aim and Objective}

The current research aims at treating the distillery effluent by using low cost adsorbent, studying effect of affecting parameters and verifying the batch data for isotherm and kinetics of solute uptake. In the present investigation wood charcoal has been used as an adsorbent for removal of organic matter from the distillery effluent. The organic matter was measured in terms of chemical oxygen demand. The optimum values of the parameters like contact time, initial COD, adsorbent dose and $\mathrm{pH}$ have been determined. The Studies were carried out on isotherm and kinetics of the COD removal by using the batch experiment data.

\section{Methodology}

The adsorbent was prepared by using wood charcoal. The wood charcoal was obtained from the coal suppliers for laundries. It was then heated to $200-250{ }^{\circ} \mathrm{C}$, then crushed and again heated for 3-4 hours in oven before using it. The average mesh size was -36 to -72 .For carrying out batch experiments, $100 \mathrm{ml}$ of effluent was taken in a conical flask and required amount of adsorbent was added to it. Then it was stirred for different contact times. The samples were filtered and then analyzed for COD. Initial and final COD was estimated by using potassium dichromate as an oxidizing agent. The sample was oxidized at $150{ }^{\circ} \mathrm{C}$ on COD digester (spectra lab make) for 2.5 hours and then titrated against Mohr's salt to determine COD.

\subsection{Preparation and Characterization of Adsorbent}

The adsorbent was prepared by using wood charcoal. The wood charcoal was obtained from the coal suppliers for laundries. It was then heated to $200-250{ }^{\circ} \mathrm{C}$, then crushed and again heated for 3-4 hours in oven before using it. The average mesh size was -36 to -72 . The adsorbent was characterized by Energy-dispersive $X$-ray spectroscopy. Testing and imaging of samples was carried out by Quanta 200 ESEM (Scanning Electron Microscope) system. Fig.1 shows the images of adsorbent with particle size. Particle size ranges from 136.5 to $453 \mu \mathrm{m}$. Average particle size was $250.5 \mu \mathrm{m}$. The minimum and maximum pore size was observed to be 3.24 and $14.82 \mu \mathrm{m}$ respectively. The average pore size was $8.04 \mu \mathrm{m}$. Composition of the adsorbent is shown in table 1. EDX(Energy Dispersed X-ray) is shown in fig.2.

Table1. Quantitative Analysis of Adsorbent

\begin{tabular}{|c|c|c|c|}
\hline Element & Weight \% & Atomic \% & Error \% \\
\hline $\mathrm{C}_{\mathrm{K}}$ & 88.51 & 91.34 & 2.88 \\
\hline $\mathrm{O}_{\mathrm{K}}$ & 10.97 & 8.50 & 14.47 \\
\hline $\mathrm{Ca}_{\mathrm{K}}$ & 0.53 & 0.16 & 23.65 \\
\hline
\end{tabular}



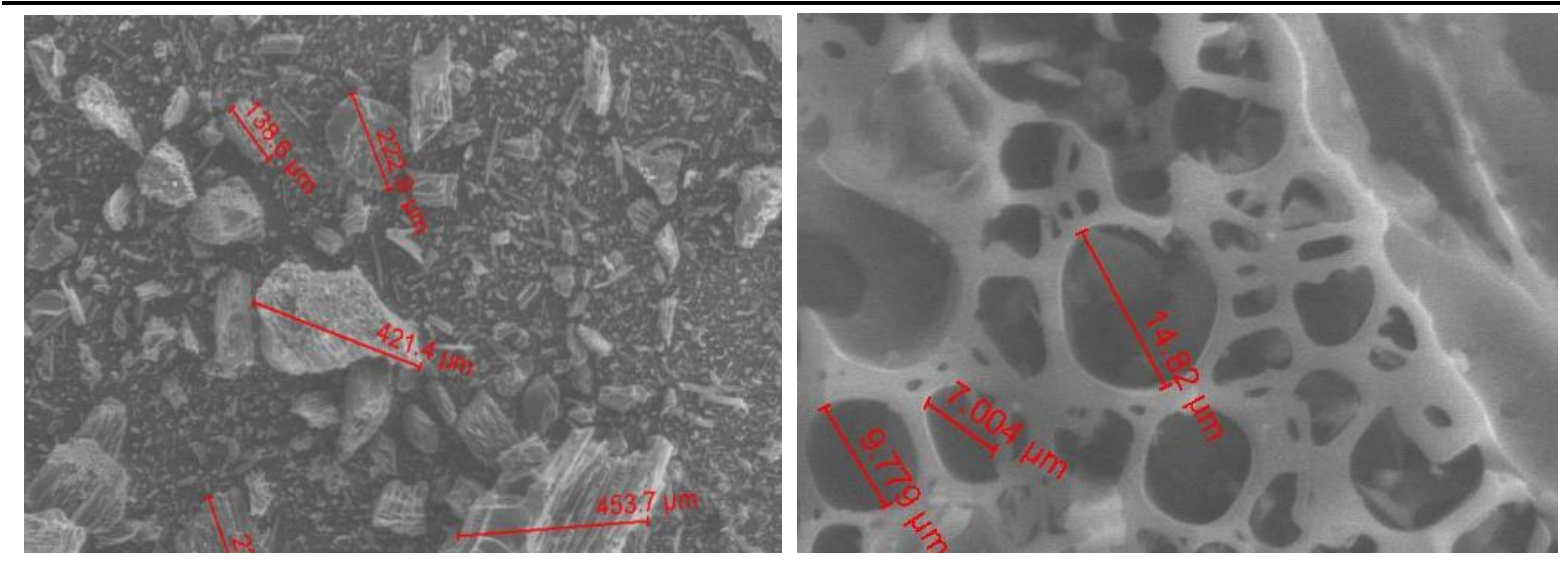

Fig1. SEM structure of adsorbent

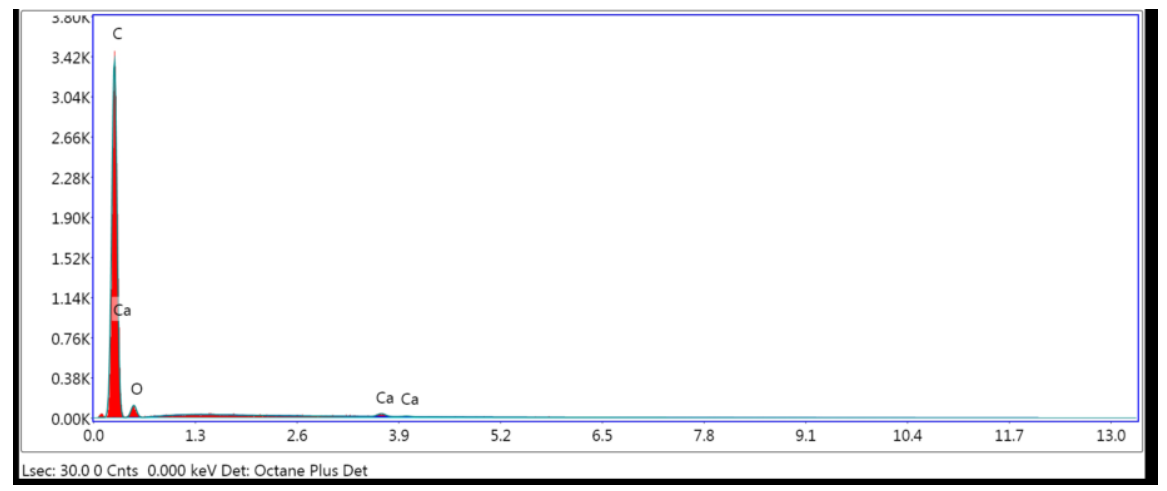

Fig2. EDX analysis of adsorbent

\subsection{Batch Experiments}

For carrying out batch experiments, $100 \mathrm{ml}$ of effluent was taken in a conical flask anda required amount of adsorbent was added to it. Then it was stirred for different contact times. The samples were filtered and then analyzed for COD. Initial and final COD was estimated by using potassium dichromate as an oxidizing agent. The sample was oxidized at $150^{\circ} \mathrm{C}$ on COD digester (spectra lab make) for 2.5 hours and then titrated against Mohr's salt to determine COD.
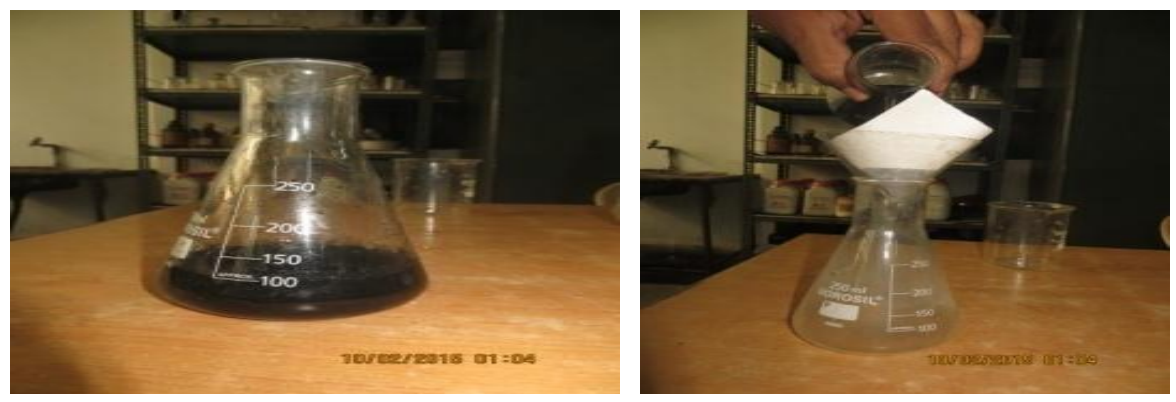

Fig3. Batch Adsorption

\section{RESULT AND DISCUSSION}

\subsection{Effect of Contact Time}

For these experiments, 5 grams of adsorbent was added to $100 \mathrm{ml}$ of effluent in $500 \mathrm{ml}$ conical flask. About 6-7 such samples were taken. Each flask was stirred for different contact times $(10,20,30,40,50,60$ minutes). As shown in fig.3,the samples were filtered and then analyzed for COD. Fig. 4 and 5 shows effect of contact time on the COD. With increase in contact time there was rapid decrease in COD initially, which later becomes very slow. The attainment of equilibrium after certain contact time can be the reason for this. The optimum contact time was observed to be 40 minutes in this experiment. This contact time was comparable with optimum contact time obtained in various similar investigations carried out for application of low cost adsorption process for COD removal $[20,21]$. 


\subsection{Effect of Initial Concentration}

For study of effect of initial concentration, the effluent having initial COD of $5997 \mathrm{mg} / \mathrm{l}$ was diluted to the COD contains using different dilution $\operatorname{ratios}(3000,1500,750,375,187 \mathrm{mg} / \mathrm{l}))$. The samples were stirred for 90 minutes, more than the time obtained in earlier experiment. Then samples were filtered and analyzed. With increase in initial concentration percentage COD removal increased rapidly up to initial concentration of $1500 \mathrm{mg} / \mathrm{l}$. Further, the percentage increase becomes less significant. At the maximum concentration of $6000 \mathrm{mg} / \mathrm{l}$, the percentage COD removal obtained was 88 percent .The effect of initial concentration is depicted in fig.6.

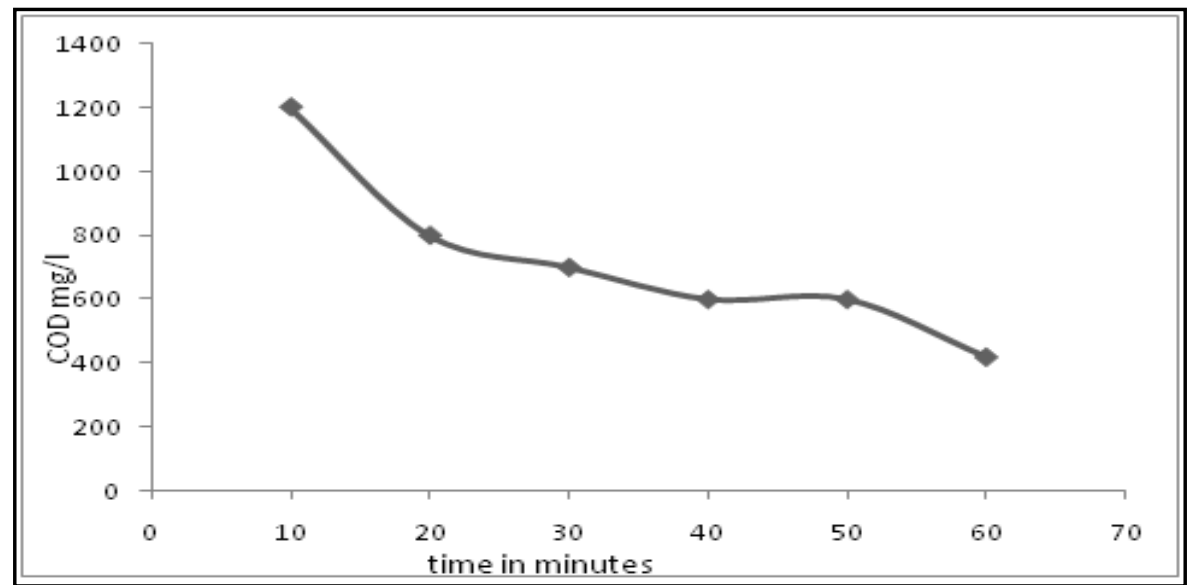

Fig4. Effect of contact time on final COD

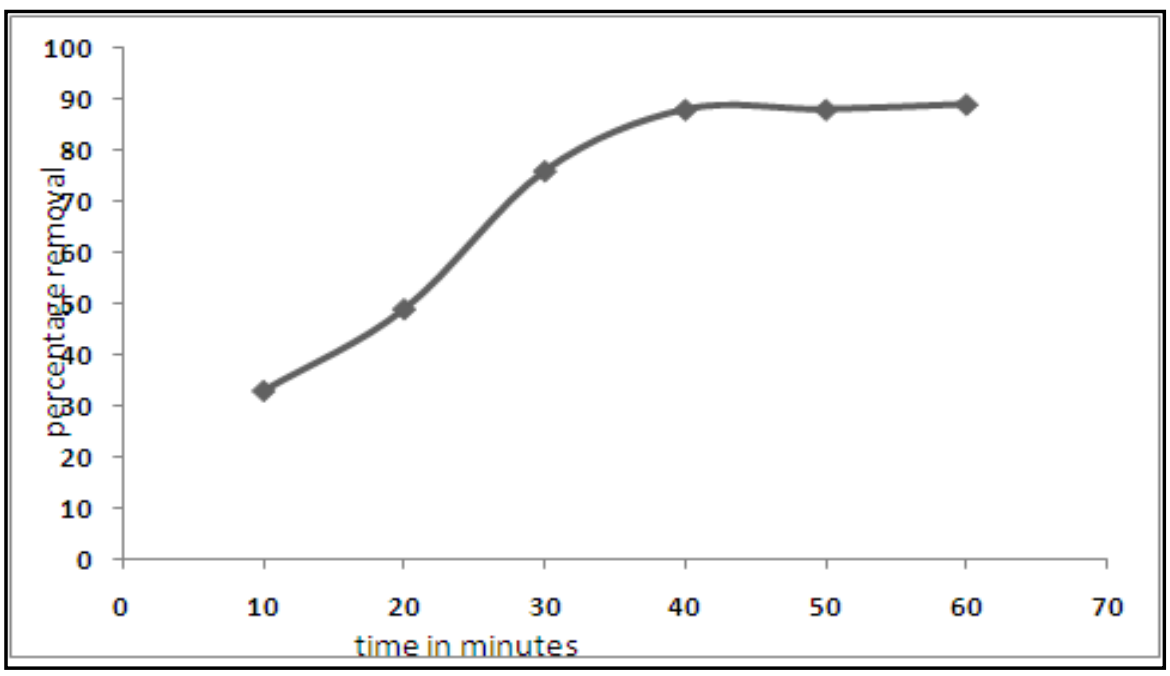

Fig5. Effect of contact time on percentage COD removal

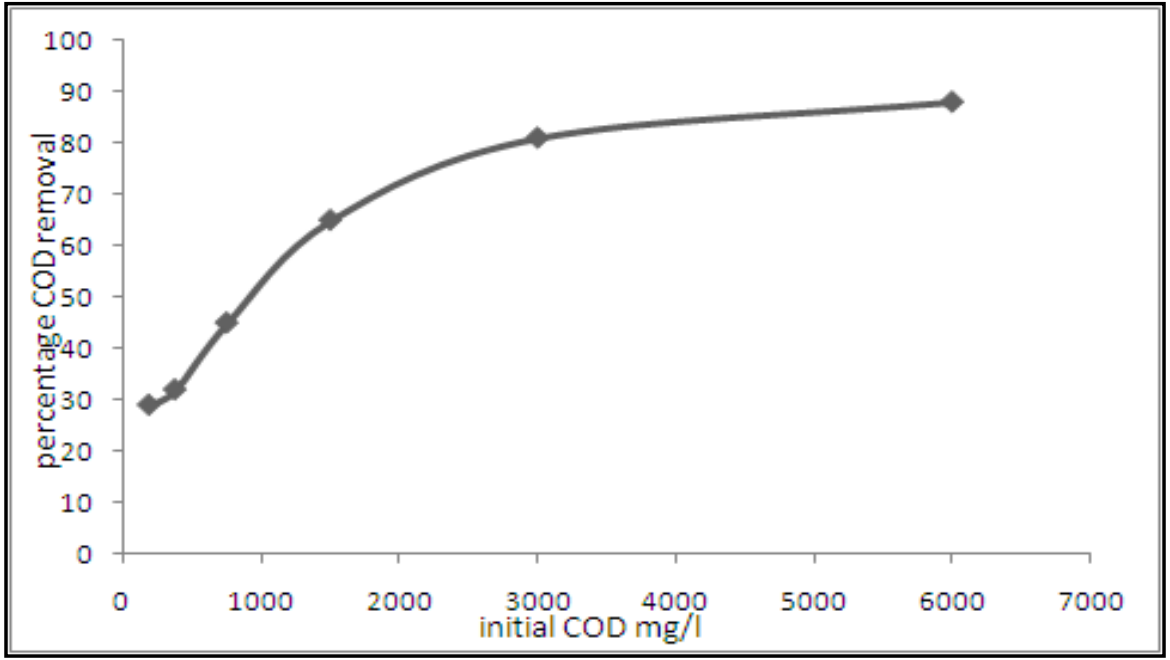

Fig6. Effect of initial COD concentration on percentage COD removal 
Solute Uptake, Isotherm and Kinetic Studies for Distillery Wastewater Treatment for Removal of Organic Matter by Low Cost Adsorbent

\subsection{Effect of adsorbent dose}

Various amounts of adsorbent dosage were added to $100 \mathrm{ml}$ of effluent having initial concentration of $5997 \mathrm{mg} / \mathrm{l}$ of COD. Fig.7 shows the effect of adsorbent dose on COD concentration. Initial concentration of COD was $5997 \mathrm{mg} / \mathrm{l}$. As shown in the figure, the COD reduction is very rapid with increase in adsorbent dose up to 8 gram. Further increase in the adsorbent dose doesn't indicate any significant reduction in COD. This may be because of formation of dense slurry and hence inability of adsorbate to reach the adsorbent sites. Thus the adsorbent dose of 8 grams $/ 100 \mathrm{ml}$ is optimum adsorbent dose. As shown in fig.8, the maximum percentage COD removal of 70 percent was obtained in this study.

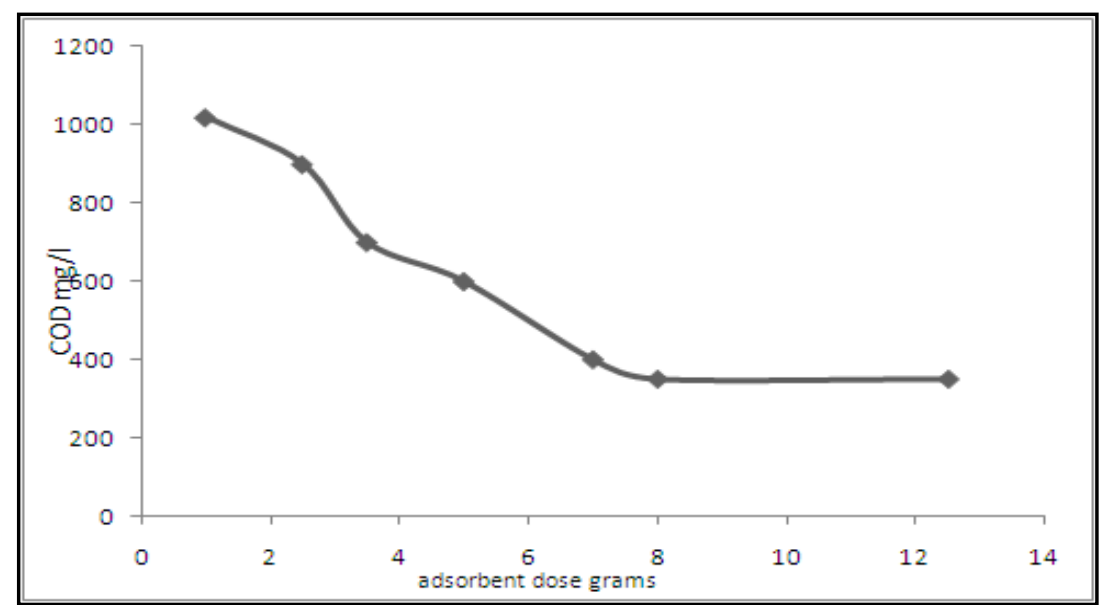

Fig7. Effect of adsorbent dose on Final COD

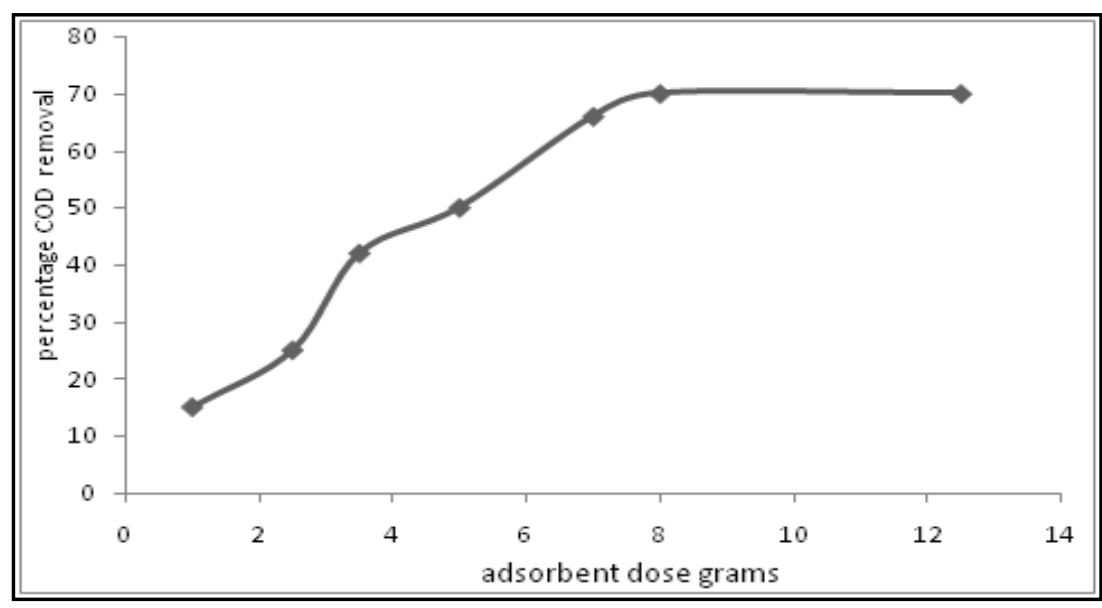

Fig8. Effect of adsorbent dose on percentage COD removal

\subsection{Effect of $\mathrm{pH}$}

These experiments were conducted with $100 \mathrm{ml}$ effluent, initial COD of $5997 \mathrm{mg} /$, adsorbent dose of 8 grams and contact time of 1 hour. The effect of $\mathrm{pH}$ on the final COD and percentage COD removal is indicated in fig.9 and 10. If $\mathrm{pH}$ was increased from 3 to 7, the adsorption also increased. Further increase in the $\mathrm{pH}$ doesn't favour the adsorption. The reason can be the effect caused by $\mathrm{OH}^{-}$ions in terms of nature of ionization and competition for active sites. The maximum percentage removal of 84 percent was obtained for $\mathrm{pH}$ value of 7 . Many investigators have reported the maximum COD removal at $\mathrm{pH}$ values ranging from 2 to $6[20,21]$. At higher $\mathrm{pH}$ the $\mathrm{OH}^{-}$ion hinder the adsorption of organic matter on the adsorbent. $\mathrm{pH}$ value of 7-8 was found to be optimum in the investigations for COD removal by waste leaves[22]. At lower $\mathrm{pH}$, the adsorption is expected to be high because of positive charge of $\mathrm{H}^{+}$ions from acids. However the results indicated that adsorption decreases with decrease in $\mathrm{pH}$ from 7 to 2 . This may be because of interference of hydronium ions, which may be formed at low $\mathrm{pH}$ values. At lower $\mathrm{pH}$, the increased concentration of $\mathrm{H}^{+}$ions may compete with the cation for sites[23]. 


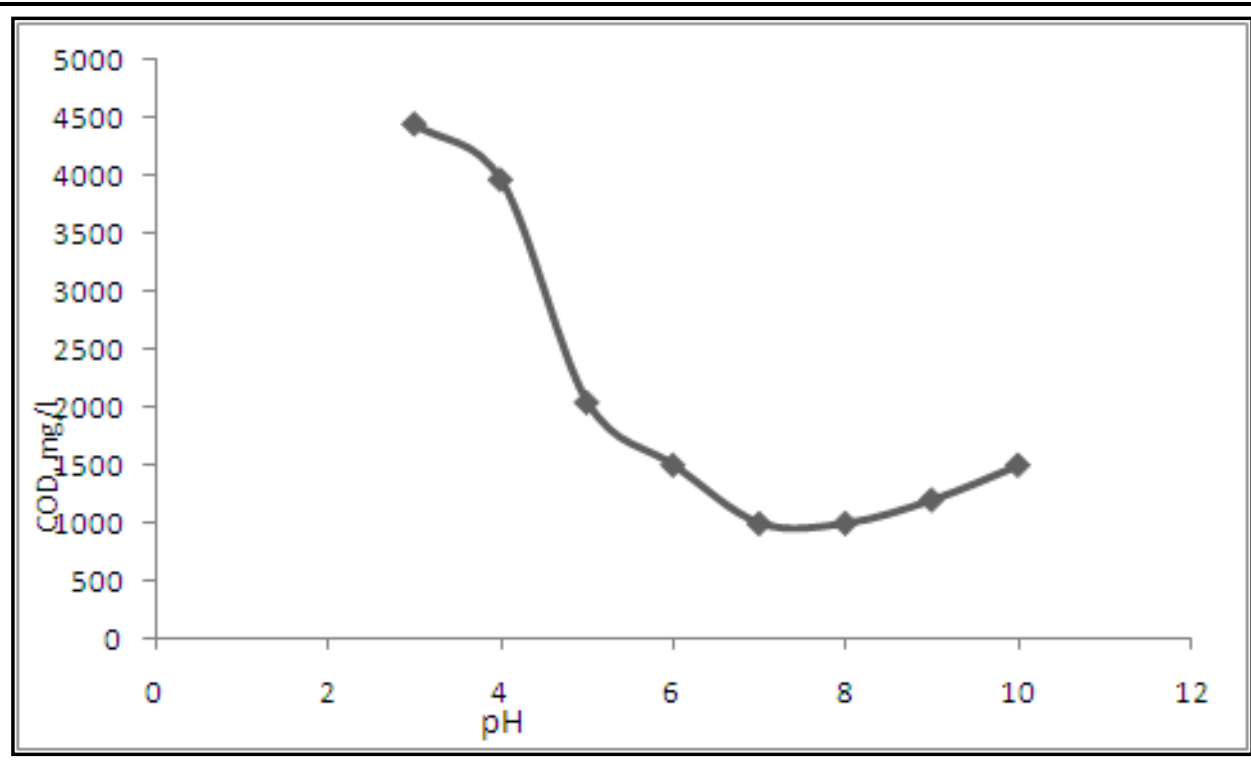

Fig9. Effect of $p H$ on final $C O D$

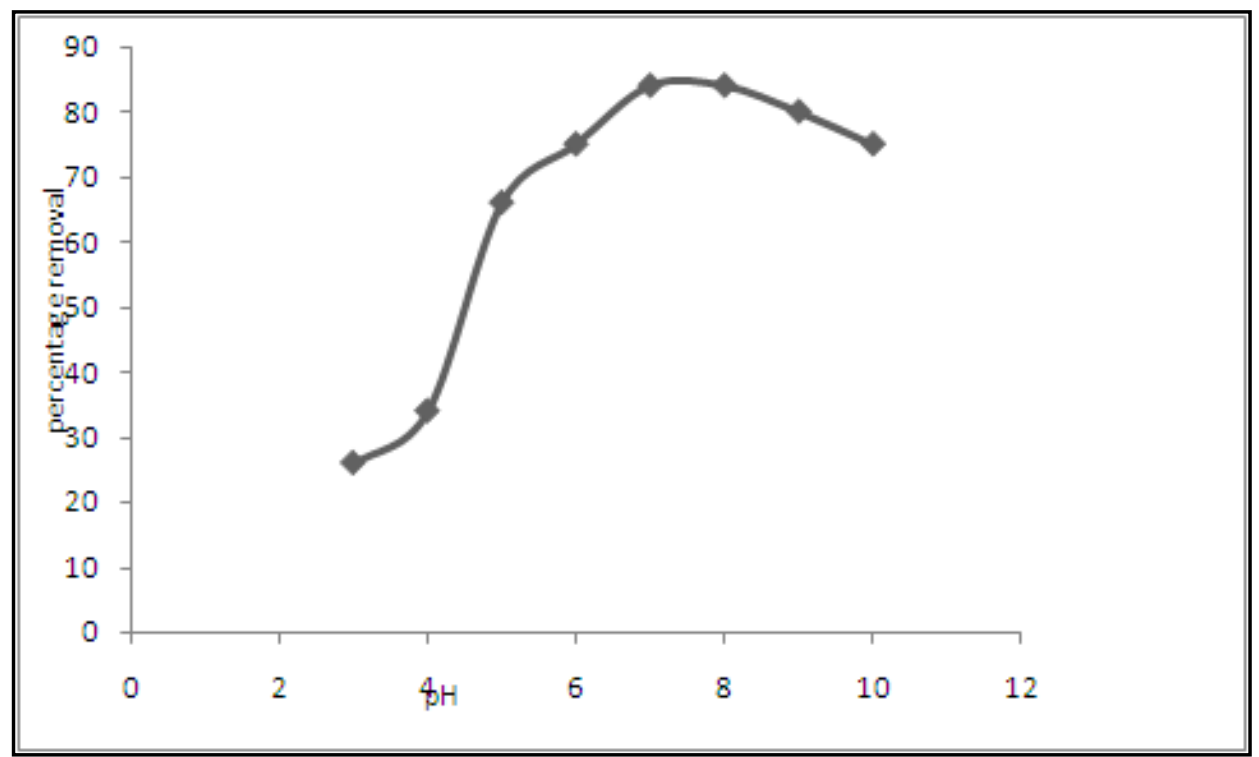

Fig10. Effect of $p H$ on percentage COD removal

\section{ADSORPTION ISOTHERMS}

Fig.11 and 12 shows Freundlich and Langmuir isotherms respectively.

Freundlich isotherm equation is given by[24]

$\frac{X}{M}=\mathrm{K} \mathrm{C}^{* 1 / \mathrm{n} \ldots \ldots . .}$

Here $\mathrm{X}$ is the COD removed per unit effluent volume, $\mathrm{M}$ is the mass of adsorbent, $\mathrm{C}^{*}$ is the equilibrium concentration. The plot of $\ln \mathrm{X} / \mathrm{M}$ verses $\ln C^{*}$ was a straight line with slope $1 / \mathrm{n}$ and intercept $\ln \mathrm{K}$. From the figure, Freudlich equation fitted reasonably well with variance $\mathrm{R}^{2}$ as 0.960 . The value of $K$ was found to be 0.155 and value of $n$ was estimated to be 0.0706 .

Langmuir equation is given by

$q e=\frac{q o b C e}{(1+b C e)}$

Maximum capacity is $\mathrm{q}_{0}$ for the adsorbents and $\mathrm{q}_{\mathrm{e}}$ is the sorption capacity for equilibrium concentration Ce. $\mathrm{q}_{\mathrm{e}}$ is $\mathrm{X} / \mathrm{M}$, i.e.COD removed per unit adsorbent. The plot of $1 / \mathrm{X} / \mathrm{M}$ verses $1 / \mathrm{Ce}$ was obtained as shown in fig.12. This equation fitted in the experimental data with $\mathrm{R}^{2}$ value as 0.90 . The value of $\mathrm{q}_{0}$ was observed to be $200 \mathrm{mg} / \mathrm{g}$. 
Solute Uptake, Isotherm and Kinetic Studies for Distillery Wastewater Treatment for Removal of Organic Matter by Low Cost Adsorbent

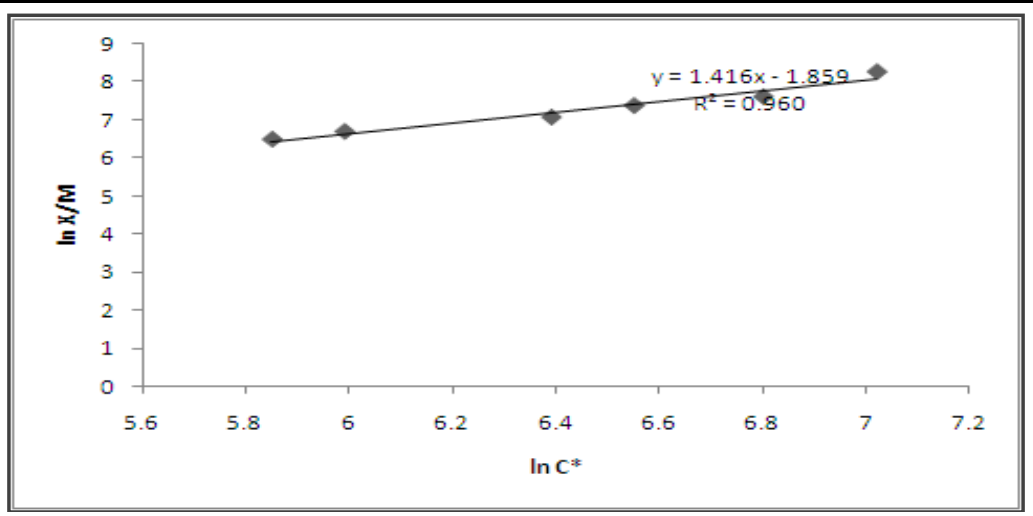

Fig11.Freundlich isotherm

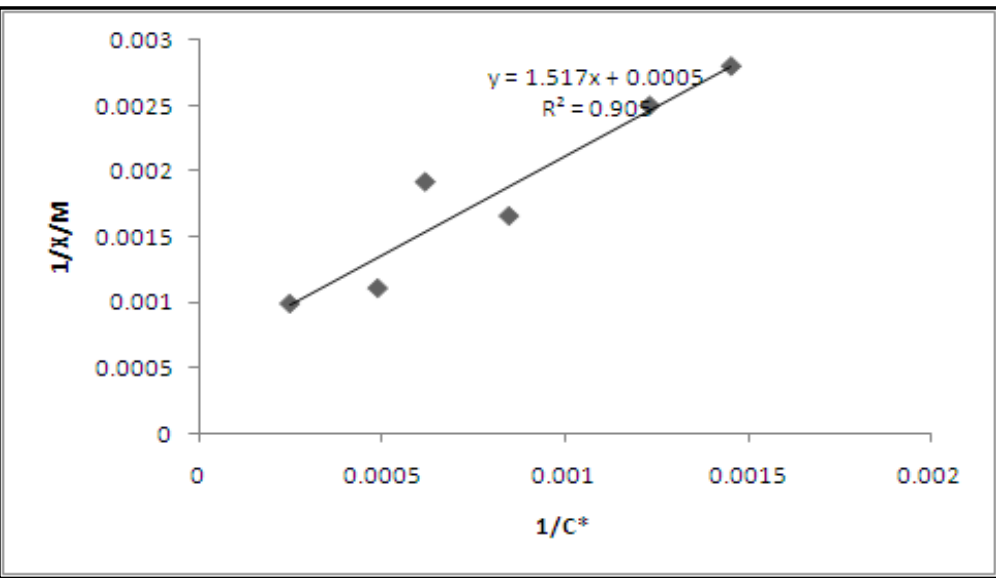

Fig12. Langmuir isotherm

\section{Kinetics OF COD ReMoval}

First order kinetic equation for adsorption is given below[25]. Here $\mathrm{q}_{\mathrm{e}}$ is the COD adsorbed at equilibrium $(\mathrm{mg} / \mathrm{g}), \mathrm{q}_{\mathrm{t}}$ is the COD adsorbed at time $\mathrm{t}(\mathrm{mg} / \mathrm{g}), k_{1}$ is the first order reaction rate constant.As shown in fig.13, the first order equation gave satisfactory fit with $\mathrm{R}^{2}$ value as 0.963 . $\mathrm{k}_{1}$ was observed to be $0.019 \mathrm{mg} / \mathrm{g} / \mathrm{min}$. The value of $\mathrm{q}_{\mathrm{e}}$ was $163.63 \mathrm{mg} / \mathrm{g}$.

$\ln \left(q_{e}-q_{t}\right)=\ln q_{e}-k_{1} \mathrm{t}$

Second order kinetic equation is given by following equation [25].As shown in fig. 14, the second order equation described the kinetics of COD removal satisfactorily with $\mathrm{R}^{2}$ value as 0.936 . The values of $\mathrm{k}_{2}$ and $\mathrm{q}_{\mathrm{e}}$ were estimated to be $0.075 \mathrm{mg} / \mathrm{g} / \mathrm{min}$ and $333.33 \mathrm{mg} / \mathrm{g}$ respectively.

$\frac{t}{q_{t}}=\frac{1}{k_{2} q_{e}^{2}}+\frac{t}{q_{e}}$

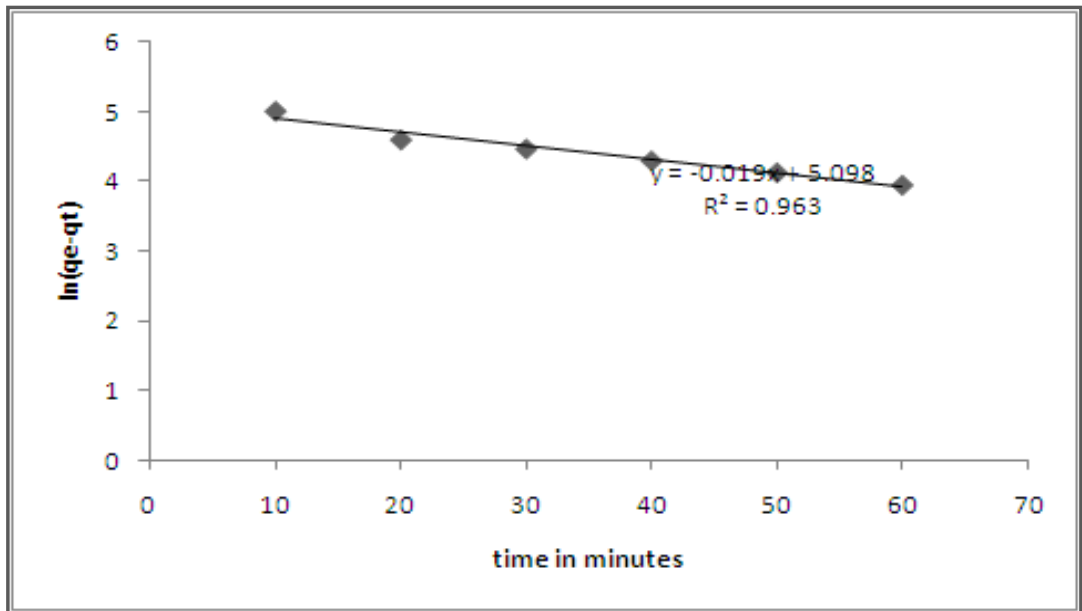

Fig13. First order kinetics 


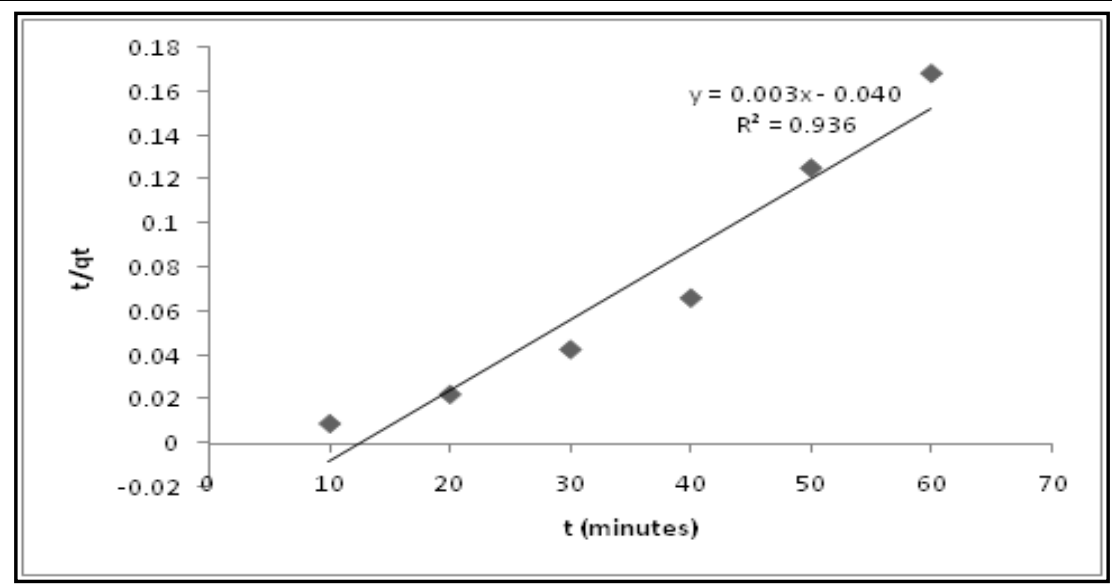

Fig14.Second order kinetics

\section{CONClusion}

The use of wood charcoal for the organic matter removal indicated satisfactory results. It was observed that the adsorption increases with contact time up to a certain time, required to reach saturation and then it remains constant. The increase in adsorbent dose increases the percentage adsorption up to certain value and then the effect is insignificant. The optimum $\mathrm{pH}$ was 7 for the COD removal. The kinetics of solute uptake follows both first and second order kinetics reasonably well. Also the adsorption followed both Langmuir and Freundlich isotherms with $\mathrm{R}^{2}$ values more than 0.9 . It can be concluded that the treatment of distillery effluent by wood charcoal adsorbent is promising, low cost and feasible alternative as the percentage removal obtained in various batch experiments was 80 to 90 percent.

\section{REFERENCES}

[1] A.A. Ahmad, B.H. Hameed(2009), Reduction of COD and colour of dyeing effluent from a cotton textile mill by adsorption onto bamboo-based activated carbon, Journal of Hazardous Materials.172 (2-3)538-1543.

[2] Dinesh Mohan, Kunwar P. Singh, Vinod K. Singh(2008), Wastewater treatment using low cost activated carbons derived from agricultural byproducts-A case study, Journal of Hazardous Materials.152 (3) 1045-1053.

[3] M. Ahamaruzzaman(2009), Role of flyash in Removal of organic pollutants from wastewater,Energy Fuels. 23 (3) 1494-1511.

[4] R. Vldlc, M.T. Saldan(1991), Role of Dissolved Oxygen on Adsorption Capacity of activated Carbon for natural and synthetic organic matter, Environ. Sci.Tecnology.25 1612-1618.

[5] X. Ren, Changlun C.M. Nagatsu, and X.Wang(2011), Carbon nanotubes as adsorbents in environmental pollution management: A review, J. Chem. Eng.170(2-3) 395-410.

[6] Ghodale M. D., Kankal S. B.(2014), Investigation of Optimum Operating Parameters for BOD \& COD Removal using Activated Carbon, International Journal of Recent Development in Engineering and Technolog. 2 (4), 38-43.

[7] Sunil J. Kulkarni, Suhas V Patil, and Y. P. Bhalerao(2011), Fly ash Adsorption Studies for Organic Matter Removal Accompanying Increase in Dissolved Oxygen, International Journal of Chemical Engineering and Applications. 2 (6) 434-438.

[8] [8] B. Shah, R. Tailor and A. Shah(2011), Adoptation of bagasse flyash a sugar industry solid waste into zeolitic material for the uptake of phenol, Env. .Progress and Sustainable Energy.30 (3)358-367.

[9] Prasad, S and G. Singh.(1994), Application of activated carbon for treatment of wastewater with special emphasis on coke oven effluents, Indian Journal Environmental Protection. 14 (9) 695-699.

[10] Krishna, R.S. and M.K.N. Yenkee(2001), Preparation of carbon from pyrolysis of coconut husk and evaluation of its adsorption characteristics, Indian Journal Environmental Protection. 17(1) ( 2001) 35-41. 
[11] Sutton, P.,Membrane(2003), bioreactors for industrial wastewater treatment: the state-of-the-art based on full scale commercial applications ,In: Proceedings of 2003 Annual Symposium of Water Environment Federation.

[12] Stuckey, D. C.; Hu, A.(2003), The Submerged Anaerobic Membrane Bioreactor (SAMBR): An Intensification of Anaerobic Wastewater Treatment, International Water Association: London.

[13] V. Khandegar and Anil K. Saroh(2014), Treatment of Distillery Spentwash by Electrocoagulation, Journal of Clean Energy Technologies. 2 (3) 244-247.

[14] R Kumaresan, N. SundaraRamakrishnan and C. Premalatha(2009), Aerobic Treatment of Distillery Wastewater in a Three Phase Fluidized Bed Biofilm Reactor, International Journal of Chemical Engineering Research .1 (1) 13-20.

[15] XolisaMelamane, Roman Tandlich and Jo Burgess(2007), Anaerobic Digestion Of Fungally PreTreated Wine Distillery Wastewater, African Journal of Biotechnology. 6 (17) 1990-1993.

[16] Anil K. Rajvanshi and NandiniNimbkar(2004), Solar Detoxification of Distillery Waste ,Nimbkar Agricultural Research Institute (NARI)Phaltan Publication. 1-7.

[17] Krishna, R.S. and M.K.N. Yenkee(2001), Preparation of carbon from pyrolysis of coconut husk and evaluation of its adsorption characteristics, Indian Journal Environmental Protection. 17(1)35-41.

[18] Ali Naghizadeh, SiminNasseri, Amir HosseinMahvi, RaminNabizadeh, Roshanak Rezaei Kalantary and AlimoradRashidi(2013), Continuous adsorption of natural organic matters in a column packed with carbon nanotubes, Journal of Environmental Health Sciences \& Engineering. 11(6) 1-6.

[19] Ademiluyi, F. T.; Amadi, S. A.; Amakama, Nimisingha Jacob(2009), Adsorption and Treatment of Organic Contaminants using Activated Carbon from Waste Nigerian Bamboo, J. Appl. Sci. Environ. Manage. 13 (3) $39-47$.

[20] Shivayogimath C.B1, ShreyaInani(2014), Treatment of biomethanated distillery spent wash by adsorption process on bagasse activated carbon, Int. Journal of Applied Sciences and Engineering Research. 3 (6) 1066-1075.

[21] Netnapid Tantemsapya, Wanpen Wirojanagud, and SantiSakolchai(2004), Removal of color, COD and lignin of pulp andpaper wastewater using wood ash, Songklanakarin J. Sci. Technol. 26 (1) $1-12$.

[22] Nagda, G K; Ghole, V S; Diwan, A M(2006), Tendu leaves refuse as a Biosorbent for COD removal from Molasses Fermentation based Bulk Drug Industry Effluent, J. Appl. Sci. Environ. Mgt. 10 (3) $15-20$.

[23] Alessandro DelleSite(2001), Factors Affecting Sorption of Organic Compounds in Natural SorbentÕWater Systems and Sorption Coefficients for Selected Pollutants. A Review, J. Phys. Chem. Ref. Data. 30 (1) 188-425.

[24] Robert E. Treybal(1981), Mass Transfer Operation. 3. 565-612.

[25] Ajaelu Chijioke John, Ibironke, Oluwafunke Lara, Adedeji, Victor and Olafisoye Oladunni (2011), Equilibrium and Kinetic Studies of the Biosorption of Heavy Metal (Cadmium) on Cassia siamea Bark, American-Eurasian Journal of Scientific Research. 6.123-130. 


\section{AUTHORS' BIOGRAPHY}

Pallavi Amale, has completed her Bachelor degree in chemical Engineering from Pune University. She has done her Masters in Chemical Engineering course from Bharati Vidyapeerth College of Engineering, Pune. She has worked as faculty in Datta Meghe College of Engineering, Airoli, Navi Mumbai. Her research interest includes wastewater treatment and advance heat and mass transfer.

Mrs. Kavita Kulkarni, is working as a chemical engineering faculty in Bharti Vidyapeeth College of Engineering, Pune. She has more than 15 years of teaching experience. She has guided many projects of post graduate students. She has presented and published many research papers in national and international journals.

Dr. Sunil J. Kulkarni, has completed his PhD from Sant Gadge baba Amravati University amd M.E. from TKIET Warananagar. He is working as faculty in Chemical Engineering Department of Datta Meghe College of Engineering, Airoli, Navi Mumbai, India. He has 15 years of teaching and research experience. Dr. Sunil is involved with different academic activities across the universities in Maharashtra. He has published and published many international review and research papers. His area of research includes adsorption, clean technology and environmental biotechnology. He is on governing body and the reviewer board of many international journals and reviewed many international papers.

Mr. A. D. Kulkarni, is working as a chemical engineering faculty in Bharti Vidyapeeth College of Engineering, Pune. He has more vast teaching and research experience. He has guided many projects of post graduate students. He has presented and published many research papers in national and international journals. 